\title{
Germany's Challenge to the Monroe Doctrine
}

At the turn of the century: migration, the cases of Venezuela and Haiti

Marilyn Séphocle

\section{OpenEdition}

\section{Journals}

Electronic version

URL: http://journals.openedition.org/plc/298

DOI: $10.4000 /$ plc. 298

ISSN: $2117-5209$

Publisher

L'Harmattan

\section{Printed version}

Date of publication: 1 January 2002

Number of pages: 177-190

ISSN: 1279-8657

\section{Electronic reference}

Marilyn Séphocle, « Germany's Challenge to the Monroe Doctrine », Pouvoirs dans la Caraïbe [Online] 13 | 2002, Online since 03 March 2011, connection on 14 November 2019. URL : http:// journals.openedition.org/plc/298; DOI : 10.4000/plc.298 
Note de recherche :

Germany's Challenge to the Monroe Doctrine

At the turn of the century: migration, the cases of

Venezuela and Haiti

Par Marilyn SEPHOCLE

\section{Introduction}

The following is a letter dated December 16, 1901 and addressed to an official of the German Embassy in Washington by a high-ranking official of the State Department:

The President in his message of the $3^{\text {rd }}$ of December 1901 used the following language:

"The Monroe Doctrine is a declaration that there must be no territorial aggrandizement by any non American power on American soil. It is in no wise intended as hostile to any nation in the Old World". The President further said : "This Doctrine has nothing to do with the commercial relations of any American power, save that it in truth allows each of them to form such as it desires. We do not guarantee any state against punishment if it misconducts itself, provided that punishment does not take the form of the acquisition of territory by any non American power".

His Excellency the German Ambassador on his recent return from Berlin, conveyed personally to the President the assurance of the German Emperor that his Majesty's government has no purpose or intention to make even the smallest acquisition of territory on the South American Continent or the adjacent islands. This voluntary and friendly declaration was afterwards repeated by the Secretary of State, and was received by the President and the people of the United States in the frank and cordial spirit in which it was offered. In the memorandum of the $11^{\text {th }}$ of December, his Excellency the German Ambassador repeats these assurances as follows : "We declare especially that under no circumstances do we consider in our

$\operatorname{PDLC~}^{\circ} 13,2002$ 
proceedings the acquisition or the permanent occupation of Venezuelan territory".

In the aforementioned memorandum of the $11^{\text {th }}$ of December, the German Government informed that of the United States that it has certain just claims for money and for damages wrongfully withheld from German subjects by the government of Venezuela and that it proposes to take certain coercive measures described in the memorandum to enforce payment of these just claims.

The President of the United States appreciating the courtesy of the German Government in making him acquainted with the state of affairs referred to, and not regarding himself as called upon to enter into the consideration of the claims in question, believes that no measures will be taken in this matter by agents of the German government, which are not in accordance with the well-known purpose above set forth, of His Majesty the German Emperor.

In his letter dated December 23, 1901 addressed to the German Emperor, Admiral von Dietrichs of the German Marine writes at length about the use of the "Vineta", the "Falke" and the "Gazelle", three German warships on the Venezuelan coast. According to the beginning of the letter the three warships would be used to defend German interests in Venezuela. At the end of the letter however von Dietrichs mentions the eventual use of six other warships, the "Victoria Louise", the "Amazone", the "Niebe", the "Hela", the "Zieten" and the "Hagen". According to the German Admiral these could be used in the event of what he describes as a "Strengthening of Germany's relations with Venezuela" or as a "Possible necessary confrontation with the Venezuelan government".

What led to this confrontation? In this paper we shall examine the Germany's role in Central America, particularly in Haiti and Venezuela at the turn of the century in light of Germany's opposition to the Monroe Doctrine.

\section{Germany's navy and colonial societies}

At the turn of the century Germany had its own brand of imperialism. German imperialism was rooted in the Wilhelminian

PDLC n ${ }^{\circ}$ 13, 2002 
Weltpolitik and in neo-mercantilism. At the time, foreign policy makers in Germany used a gamut of tools to support imperialism. One of them was a fleet of ships doing maneuvers in the Caribbean basin and reporting regularly to their government. A second tool was the proliferation of German colonial societies. Usually, upon their retirement these same officers would later join such pro-imperialist lobbies as the "pan-German league" or "the colonial league". The third tool was emigration. Emigration was backed by the establishment of German schools and churches. Religion, however, failed to attract followers. Most of the Germans residing in Venezuela and Haiti had either embraced the Catholic faith or were non-practicing Protestants.

Even after its unification, Germany remained essentially a middle European nation, non-threatening to its nine neighbors. Germany was until the 1880 s not extremely militarily oriented.

But that was about to change : in the 1890 s a military culture developed. General Alfred von Schlieffen and General von Tirpitz embodied the new German military power. Admiral von Tirpitz (18491930) was the father of the German marine. Although he did not articulate a clear policy for Germany in terms of its new aspirations on the world stage, he was convinced of that an impressive fleet would win his country, the respect of its neighbors and would be a war deterrent. The cult of the uniform, the expansion of the navy which became second only to that of Great Britain, the founding of such institutions as the "Deutsche Flottenverein" (1898), the "Kolonialverein", the "Alldeutsche Verband" marked the new German Weltpolitik. Germany was far more active in Africa where it had acquired Cameroon, Zanzibar, Togo, Southwest Africa. In Latin America and the Caribbean, the Reich was banking more on establishing a strong presence, strengthening the already settled German colonies and sending new groups of Germans to places like Venezuela where settlements such as "la Colonia Tovar" were already in their second or third generation. In Haiti a relatively large community of German merchants played an important role in the island's economy.

$\operatorname{PDLC~} n^{\circ}$ 13, 2002 


\section{Germany's New Markets in Latin America and the Caribbean}

Already in 1847, Germany had 162 consulates in Latin America and in the Caribbean. As early as 1827, Germany had appointed Georg Gramlich as its first Consul to Guaira, Venezuela. This first step in diplomatic relations between Germany and Venezuela was followed 10 years later by the Treaty of Commerce and Trade. This major historical event steadily increased the sale of German goods to Venezuela. Until the 1850s, Germany's adventures in Latin America and the Caribbean represented no challenge to the Monroe Doctrine.

One culmination point in the establishment of new found markets was the founding on the $27^{\text {th }}$ of May 1847 (date of the $10^{\text {th }}$ anniversary of the Treaty of Commerce) of the "HamburgAmerikanische-Packeffahrt-Aktiengesellschaft" (HAPAG). This association was the work of 33 enterprising businessmen from Hamburg under the stewardship of August Bolten, an influential shipbroker. It increased from 5 to 32 the number of German boats in Venezuelan waters, thus contributing significantly to German trade. In 1874, HAPAG also took on the role of postal service for the entire region of the Caribbean, becoming the most efficient postal service until 1879. What had begun as a German venture to the Americas to New York and Venezuela constituted in 1871 a large percentage of Germany's foreign exports reaching 33 harbors in the Americas along the Atlantic coast.

One of the major trading nations of the end of the $19^{\text {th }}$ century, the German empire exported high value-added goods at a faster rate than it imported such goods as tobacco, leather, copper, zinc and other minerals, cotton, cocoa; thus contributing to a healthy $4,5 \%$ annual industrial growth rate maintained between 1866 and 1872 and again between 1890 and 1913. At the turn of the century, between 1890 and 1904 , Germany's foreign trade had increased by $66 \%$, which was the highest foreign trade increase in the world. The United States took a close second place in trade increase with a $59 \%$ increase for the same period. According to the German Imperial Navy Office, German investments in Central and Latin America exceeded the amount of

PDLC n ${ }^{\circ}$ 13, 2002 
German investment in North America. Of the 7,735 million Mark invested overseas in 1898, 1,200 million were invested in Central America and the Caribbean and approximately 400 million Mark were invested in South America, and 1,200 million Mark in the Eastern part of the continent while approximately 2,000 million Mark were placed in North America and Canada.

These German Venezuelan relations that had started on a rather positive footing started to sour very quickly as early as 1851 when the Venezuelan government rescinded the Trade treaty, due in part to the disturbances that existed in Venezuela at the time.

Monroe Doctrine of December 2, 1823 and Gustav Schmoller's reaction

After 1871 emboldened by a strong economy and feeling the need to expand and to rival other European powers particularly Great Britain, Germany began to dream of an empire beyond its European borders.

"In the coming century we must desire at all casts a German colony of some 20 to 30 millions people in South America. This is impossible without warships, which provide secured maritime communications and a presence backed by force" said the German economist Gustav Schmoller in 1900. Such statements were in direct opposition to the Monroe Doctrine which had self-appointed the United States of America as the sole gendarme of the region.

\section{Colonizing South America : an old German Dream}

As early as 1528 some "Germans" had their eyes set on Venezuela or "little Venice". The financial house of Weiser (one of the financial tycoons that financed the slave trade) was granted permission by Emperor Charles V to colonize Venezuela. Ambrosius Dalfinger, Nikolaus Federmann, Franz Lebzelter, Sebastian Rentz, Hieronymus Sayier and Georg Speyer were among the notables from the city of Ulm who set out for the adventure. Twenty-seven years later the aspirations of the Weiser House were brought to a halt by the Spanish. This did not prevent the German financial houses of Welser and Fulda to participate on a financial basis to the slave trade, particularly on the

$\operatorname{PDLC~} n^{\circ}$ 13, 2002 
Dutch side. The enterprise was particularly lucrative in Surinam where the interests they earned were rather high.

\section{From Dream to Reality}

It is not until the $19^{\text {th }}$ century that the Germans began to dream again of Latin America. Germany shifted completely its emigration policy from heavy taxation of candidates to emigration to "unfettered and untaxed" emigration. The state of Baden took the lead in relaxing emigration policy. Between 1840 and 1849 Baden seven subsidized the emigration of farmers. It is during that era that a number of German settlements sprung up in Latin America. Blumenau formed in 1850 in the state of Santa Catarina in Brazil was a prime example. So were the Baradero and the Tornquist colonies in Argentina. Chile also welcomed 30,000 Germans in the mid $19^{\text {th }}$ century. The period of German settlement in Latin America also coincides with the settlement of Germans in the United States. From the mid 1850s until the 1870s, German settlements of Latin America and the Caribbean were not perceived by politicians in the United as a challenge to the Monroe Doctrine because German émigrés had acquired the reputation of assimilating very easily in their new found societies.

In 1843 Venezuela also became the stage of German settlement, welcoming 400 Germans from none other than the state of Baden. The Germans settled on the estate of Manuel de Tovar and their settlement became known later as "la Colonia Tovar". La Colonia Tovar with its multitude of German restaurants celebrated its $150^{\text {th }}$ anniversary in 1983 with fanfare, recognized as one of the touristic spots in Venezuela. What started out as migration out of necessity for German farmers escaping hardship became later on for the Berlin political elite the dream of a German Reich on the other side of the Atlantic. These various German settlements in Latin America posed initially no threat to the Monroe Doctrine. However, by the end of the $19^{\text {th }}$ century this picture had dramatically changed. By the end of the $19^{\text {th }}$ century German settlements were backed, at least theoretically, by a proliferation of colonial associations such as the German Colonial League, the Pan-German league, the Navy League, the "Kolonisationsverein", the German Colonial Office and on a more

PDLC n ${ }^{\circ}$ 13, 2002 
pragmatic note, the "Deutscher Wirtschaftsverband For Sod und Mittelamerika".

The membership of these organizations increased tenfold between the mid 1880s and the early 1890s counting among its most active members a large percentage of retired naval officers. Politically these organizations were on the right and far right of the political spectrum of the Reich. They did not pay any attention to German immigrants to North America whom they considered "lost" to America. They focused on Latin America and the Caribbean where they hoped to expand their empire. Among the dreamers were Professor Ernst Hasse of Leipzig. Secretly hoping that the "stronger" Germanic people would replace the "weaker" Spaniards in Latin America, the head of the Pan-German League (Alldeutscher Verband) had conceived a plan where his society would purchase large farms in Argentina, Brazil, Chile, Paraguay and Uruguay for the purpose of increasing German settlements in those countries. It is worth noticing here that his plan was not a novelty. It had already been successfully implemented by the Anglo-Saxons against the Indians in North America. Bearing in mind the failure of the Germans of la Colonia Tovar to uphold their "Deutschtum" (germanity), one of the preconditions Ernst Hasse had set was that these settlements be established as "future colonial lands for unmixed German populations". Ernst Hasse is also quoted as saying : "Our future lies in South America [...] only there will we be able to found the New Germany".

Echoing Hasse's sentiment, Max Ploddemann, President of the German-Brazilian Club advocated that the Reich curb migration to North America and direct to South America where Germans could "remain German and stay in touch with their homeland". Colonial organizations and some private citizens were relentlessly exercising pressure on the government to step up migration to South America and to guarantee to German citizens abroad the German citizenship not only to migrants but to their successive generations.

$\operatorname{PDLC~n}^{\circ}$ 13, 2002 
The German Challenge to the Monroe Doctrine lost its Momentum

Meanwhile the German government was decreasingly responsive to such pressures. As a matter of fact, unable to protect a large number of citizens, in 1904 shortly before the Venezuelan blockade the German government saw the widespread granting of German citizenship to future generations of Germans as an impedimen to the blockade. It would have forced the Reich to be responsible for the lives of too many German citizens abroad. Opposition to emigration to Venezuela came from none other than Friedrich Count $\mathrm{zu}$ Eulenburg, the Prussian Minister of Interior who warned the government and his compatriots about the instability of the Venezuelan government, its volatile political and social climate and worst of all its "climatic conditions" ! One valid point in the Minister's argument was the scrupulousness of emigration speculators who tended to lure artisans, domestic workers and farmers to the Venezuelan adventure while taking advantage of them.

The Germans had hoped that the experience of their compatriots in Latin America would be vastly different from that of their compatriots of North America. It turned out that the two experiences were very similar. Both groups assimilated in their newly found societies. In both cases they intermarried with the local population, deserted German schools, adopted with pride the ways of their new home.

A Gap Between the Rhetoric of the German Colonial Societies and the Realities faced by their Compatriots Abroad

There was a big gap between the German colonial societies that strongly advocated a strong German colonial empire upholding German values and the reaction of their compatriots once in their new country. There was also a huge gap between the German colonia societies push for emigration and the German government's effort to curb emigration through such laws as the Heydt-rescript. Friedrich von Eulenburg, the Prussian Minister of Interior had publicly opposed German emigration to Venezuela on June 22, 1875 before the Hamburg Senate.

PDLC $n^{\circ}$ 13, 2002 
Another deterrent to emigration was the Venezuelan citizenship law that prevented new immigrants from assuming important political posts and required a waiting period of at least two years before the granting of citizenship status. This might seem an insignificant amount of time in light of immigration laws practice in today's various industrialized nations, however, for the time it amounted to an exceptional measure for aliens coming from a European nation.

Bismarck and Wilhelm II on the Monroe Doctrine and Roosevelt's Counteraction

Before Bismarck retirement, there were two philosophies in Germany regarding German influence in Latin America, that of Bismarck and that of Emperor Wilhelm II. While Emperor Wilhem II harbored dreams of a German empire in Latin America and rejected the Monroe Doctrine, Bismarck adopted a more cautious attitude and occasionally voiced his opinion against extending German influence on the other side of the Atlantic. Later in 1897 a retired Bismarck had slightly rescinded his views denouncing the Monroe Doctrine as "an insolent dogma", "a presumptuous idea".

It is worth noticing here that both Roosevelt and Wilhem II decried what they described as the inefficiency of Latin American rulers, their mediocre handling of their political and social affairs as much as they complimented each other on their noble ideals and their mastery of politics. In their epistolary exchange one could find to top it all a common conviction of the superiority of their race and its ability to rule the world.

Overall the United States had misread some of the alarming signals that Germany was sending. The United States was completely apathetic to Germany's ambitions between the 1850s and the $1870 \mathrm{~s}$, at the height of German migration to Latin America and the Caribbean. On the other hand, the United States overestimated the German possibility of fulfillment of its dream in South America and the Caribbean in the last two decades of the $19^{\text {th }}$ century and at the beginning of the twentieth century when German migration to Latin America and the Caribbean had decreased and Germany, far more focused on European events, no longer obsessed about a colonial

$\operatorname{PDLC~n}^{\circ}$ 13, 2002 
empire in Latin America. This is due to the fact that the United States was listening mostly to the claims of the German colonial societies and far less to the diminishing migration of Germans to Latin America. Washington was also far more concerned with the sheer size of the German Navy, the second in the world, than with the degree to which it was politically backed at home.

The sinking of the Haitian gunboat "Crète à Pierrot" and the German violation of Brazilian sovereignty in 1893 were examined in Washington as clear threats to the Monroe Doctrine. The United States paid far more attention to the remarks made by Wilhelm II on the Monroe Doctrine than to the type of envoy he sent to Washington, an obscure diplomat married to an American citizen. Finally on January 17, 1903 German American relations hit an all time low when the German gunboat "Panther" returned fire leveling Fort San Carlos in Maracaibo, Venezuela. In 1903 a war between Germany and the United States had been barely avoided.

The American response to the perception of German threat was the Roosevelt Corollary of 1904. The Corollary reinforced the Monroe Doctrine by making the United States the arbiter of disputes between Latin American powers and European powers. Thus the United Sates could use force "if necessary" to guaranty that Latin American powers pay their debt to European nations.

Germany was not the only power to have difficulties with Venezuela. At the turn of the century, Venezuela was the Black sheep of international politics. Whether under the rule of Antonio Guzman Blanco or under Cipriano Castro, Venezuela had been invaded twenty two times by Colombia between 1859 and 1901. It had broken diplomatic relations with France, Belgium, the Netherlands, Great Britain, Germany. Reasons for the freeze in these diplomatic relations range from Dutch assistance to rebel group, to border disputes with Great Britain over Guyana, to Venezuela's inability to pay its foreign debt. All of these reasons were often intertwined. Taking advantage of Venezuela's weakness many European powers claimed the Central American country. Germany was not the only country that took military measures against Venezuela in return of its debt payment, in

$\operatorname{PDLC} n^{\circ}$ 13, 2002 
1898 Italy sent a squadron to the central American country for the same reason.

Germany and its gunboat Diplomacy in Haiti the Batsch Case

Haiti offered a scenario that was eerily similar to that of Venezuela. In the Franco-Prussian war of 1870, Haiti had voiced its sympathy for its former colonizer to the disappointment of Haiti's sizeable opulent German population. On June 11, 1872 two German warships, the Vineta and the Gazelle were sent to the first Black republic on a mission to collect debts on behalf of German merchants. The underlying intention as to intimidate the small nation and give it a lesson in Realpolitik about Prussian power in the world in the aftermath of the Franco-Prussian war, a muscular method customary to powerful nations. Captain Batsch demanded the retribution of the debts plus indemnities. When Haiti seemed to delay, the German captain seized on the same day Haitian warships and returned them only when the sum was gathered. "With the special finesse Hohenzollern diplomacy reserved for people of color, the German boarding parties left calling cards. When the Haitians were allowed back, they found their cherished flag spread out on the bridge of each ship, smeared with shit [...] It was the republic's first contact with the methods of German diplomacy". To add insult to injuries, the same captain was sent back to Port-au-Prince a few months later for a "visit of courtesy".

\section{The Loders case}

More telling even was the Loders case twenty-five years later. In 1897, shortly after Simon Sam was elected ruler of Haiti by his assembly, a case similar to that of Batsch was to inflict the most profound humiliation on Haiti.

Emile Leiders, a German national and livery stable keeper found himself in trouble with the Haitian authorities over an unfulfilled contract matter. Jailed and fined, he was released one month after his arrest at the demand of Count von Schwerin, then deported to Germany. Unsatisfied with the release, Count Schwerin, convinced of the superiority of his people over the Haitians, wanted to take the case further to the President of Haiti, Simon Sam, requesting that the latter dismiss the judges and the police involved in the case. In their Book

$\operatorname{PDLC} n^{\circ} 13,2002$ 
Written in Blood, the Heinzs describe the situation that ensued the following way : "[...] two German warships, S.M.S. Charlotte and Stein, anchored off Port-au-Prince, and their Commodore, Kaptan-zurSee, August Thiele, sent word ashore that commencing at 1:00 p.m., he would sink all Haitian warships present, destroy the Palais National, and bombard Port-au-Prince, providing the following terms were not acceded to a $\$ 20,000$ indemnity to Loders, and his readmission to Haiti" a formal apology to the German government, a 21 gun salute to the imperial colors, and a reception at the palace for Count Schwerin. To the diplomatic corps collective remonstrance, Thiele on his quarterdeck coldly replied that Berlin's orders allowed no deviations ; unless the Haitian flag was replaced by a white flag before 1:00 p.m., the bombardment would proceed. Down came the colors; up went the white flag. By four o'clock the indemnity had been scraped up, and, one hour later, Loders came ashore. At sunset, Fort National saluted the German flag. Schwerin, in full diplomatic tenue, stalked icily to the palace for the reception U.S. Minister Powell called "an unpleasant affair".

In both instances, in the Batsch case of 1872 and in the Leiders case of 1897, the apparent silence and the non-interventionist attitude of the United States could seem out of character given the country's self appointed role in the region. This lack of intervention is best summarized in President Roosevelt declaration of December 3, 1901, "We do not guarantee any state against punishment if it misconduct itself, provided that punishment does not take the form of acquisition of territory by any non American power". A few months prior to the Batsch incident, the Haitians were facing a similar situation and confronting the Spaniards over the "Hornet", an anti-Spanish rebel boat run by Blacks and which had found shelter in the Haitian waters. The United States intervened escorting the boat to Baltimore for the simple reason that it wanted Spain out of Cuba, which Southerners had dreamt of possessing. In the case of the Germans, no matter how unpleasant the situation might have been, from an American point of view, it was not worth fighting for, because the Germans were not enemies and had not officially claimed the island. They had "only" humiliated it. Given the way Blacks were considered by Americans as inferior, was unimportant. In light of the Roosevelt declaration, the

$\operatorname{PDLC} n^{\circ}$ 13, 2002 
American perception could even have been that Haiti was duly punished. The utter humiliation and Haiti's inability to fight back could have been perceived by the United Sates, not so much as a challenge to the Monroe Doctrine but rather as a well-deserved lesson to a Black group that had the nerves of forming a nation. It further confirmed both American and German opinions on the inability of non Anglo-Saxon and non-Germanic people to govern and defend themselves.

Germany was to test the Monroe Doctrine once more in the summer of 1914, when its warships threatened to seize the Haitian customhouses at Port-au-Prince, Jacmel and Cape Haitian. Initially, Germany's aspirations in Latin America and the Caribbean represented a real challenge to the Monroe Doctrine. Germany's navy, its colonial societies and industrious merchants were indeed the engine of the Reich's Weltpolitik. A booming economy coupled with a dynamic German migration to Latin America and the Caribbean had dueled hope, among some in the Wilhelmstrasse, of building a true empire on the other side of the Atlantic. However, at the turn of the century, there was a gap between dream and reality. The dream was that German migrants would remain German and uphold German values, and would increasingly replace what they perceived as the "inferior" races, in a manner similar to that of the Anglo-Saxon in North America. The reality was that German immigrants assimilated into their new environment and mixed with the local population. Another reality not anticipated by the Berlin colonial elite was the decrease of migration due to local laws on both sides of the Atlantic. While gunboat diplomacy inflicted humiliation and pain to countries such as Venezuela Haiti, it left the Monroe Doctrine almost unchallenged.

\section{BIBLIOGRAPHY}

- Daniels Josephus, “The Problem of Haiti”, The Saturday Evening Post, July 12, 1930.

- Fiebig von Hase Ragnhild, Lateinamerika als Konfliktherd der deutsch-amerikanischen Beziehungen, Gottingen, Vandenhoeck \& Ruprecht, 1986.

$\operatorname{PDLC~n}^{\circ}$ 13, 2002 
- Die Beziehungen Deutschlands zu Venezuela, Frankfurt am Main, Peter Lang, 1991.

- Written in Blood, New York, 1991.

- Germany's Empire in Venezuela, 1871-1914, Princeton N.J., Princeton University Press.

- Zwischen Weltpolitik Doktrin, Stuttgart, Heinz, 1992.

- Philipp von Huten in Venezuela, Darmstadt, Turris Verlag, 1972.

- Bremer Kaufleute in den Freihafen der Karibik, Bremen, Selbstverlag des Staatsarchivs Bremen, 1995.

- Neue Welt, Dritte Welt, Tübingen, Francke, 1994.

- Los Alemanes en Venezuela, Caracas, Asociacion Cultural Humboldt, 1985.

- Haiti, Arroganz im Armen Haus, Kbln, ISP, 1996.

- Auswartiges Amt. Abt. II, Handel [...] mit Venezuela, vol. 19, pp. 75-82, Beton und Monierbau to Foreign Office, Dec. 21, 1986. 